Solid Earth, 10, 79-94, 2019

https://doi.org/10.5194/se-10-79-2019

(C) Author(s) 2019. This work is distributed under

the Creative Commons Attribution 4.0 License.

\title{
Correlation between tectonic stress regimes and methane seepage on the western Svalbard margin
}

\author{
Andreia Plaza-Faverola ${ }^{1}$ and Marie Keiding ${ }^{2}$ \\ ${ }^{1}$ CAGE-Centre for Arctic Gas Hydrate, Environment, and Climate; Department of Geosciences, UiT The Arctic University of \\ Norway, 9037 Troms $\emptyset$, Norway \\ ${ }^{2}$ Geological Survey of Norway (NGU), P.O. Box 6315 Torgarden, 7491 Trondheim, Norway
}

Correspondence: Andreia Plaza-Faverola (andreia.a.faverola@uit.no)

Received: 18 February 2018 - Discussion started: 18 April 2018

Revised: 7 December 2018 - Accepted: 18 December 2018 - Published: 15 January 2019

\begin{abstract}
Methane seepage occurs across the western Svalbard margin at water depths ranging from $<300 \mathrm{~m}$, landward from the shelf break, to $>1000 \mathrm{~m}$ in regions just a few kilometres from the mid-ocean ridges in the Fram Strait. The mechanisms controlling seepage remain elusive. The Vestnesa sedimentary ridge, located on oceanic crust at a depth of 1000-1700 m, hosts a perennial gas hydrate and associated free gas system. The restriction of the occurrence of acoustic flares to the eastern segment of the sedimentary ridge, despite the presence of pockmarks along the entire ridge, indicates a spatial variation in seepage activity. This variation coincides with a change in the faulting pattern as well as in the characteristics of the fluid flow features. Due to the position of the Vestnesa Ridge with respect to the Molloy and Knipovich mid-ocean ridges, it has been suggested that seepage along the ridge has a tectonic control. We modelled the tectonic stress regime due to oblique spreading along the Molloy and Knipovich ridges to investigate whether spatial variations in the tectonic regime along the Vestnesa Ridge are plausible. The model predicts a zone of tensile stress that extends northward from the Knipovich Ridge and encompasses the zone of acoustic flares on the eastern Vestnesa Ridge. In this zone the orientation of the maximum principal stress is parallel to preexisting faults. The model predicts a strike-slip stress regime in regions with pockmarks where acoustic flares have not been documented. If a certain degree of coupling is assumed between deep crustal and near-surface deformation, it is possible that ridge-push forces have influenced seepage activity in the region by interacting with the pore-pressure regime at the base of the gas hydrate stability zone. More abundant seepage on the eastern Vestnesa Ridge at present may be
\end{abstract}

facilitated by the dilation of faults and fractures favourably oriented with respect to the stress field. A modified state of stress in the past, due to more significant glacial stress for instance, may explain vigorous seepage activity along the entire Vestnesa Ridge. The contribution of other mechanisms to the state of stress (i.e. sedimentary loading and lithospheric flexure) remain to be investigated. Our study provides a firstorder assessment of how tectonic stresses may be influencing the kinematics of near-surface faults and associated seepage activity offshore of the western Svalbard margin.

\section{Introduction}

Hundreds of gigatonnes of carbon are stored as gas hydrates and shallow gas reservoirs in continental margins (e.g. Hunter et al., 2013). The release of these carbons over geological time, a phenomenon known as methane seepage, is an important contribution to the global carbon cycle. Understanding and quantifying seepage has important implications for ocean acidification, deep-sea ecology, and global climate. Periods of massive methane release from gas hydrate systems (e.g. Dickens, 2011) or from large volcanic basins like that in the mid-Norwegian margin (e.g. Svensen et al., 2004) have been linked to global warming events such as the Palaeocene-Eocene thermal maximum. In addition, methane seepage and near-seafloor gas migration have implications for geohazards, as pore-fluid pressure destabilization is one factor associated with the triggering of submarine landslides (e.g. DeVore and Sawyer, 2016; Urlaub et al., 2015). It is well known that seepage at continental margins has been oc- 


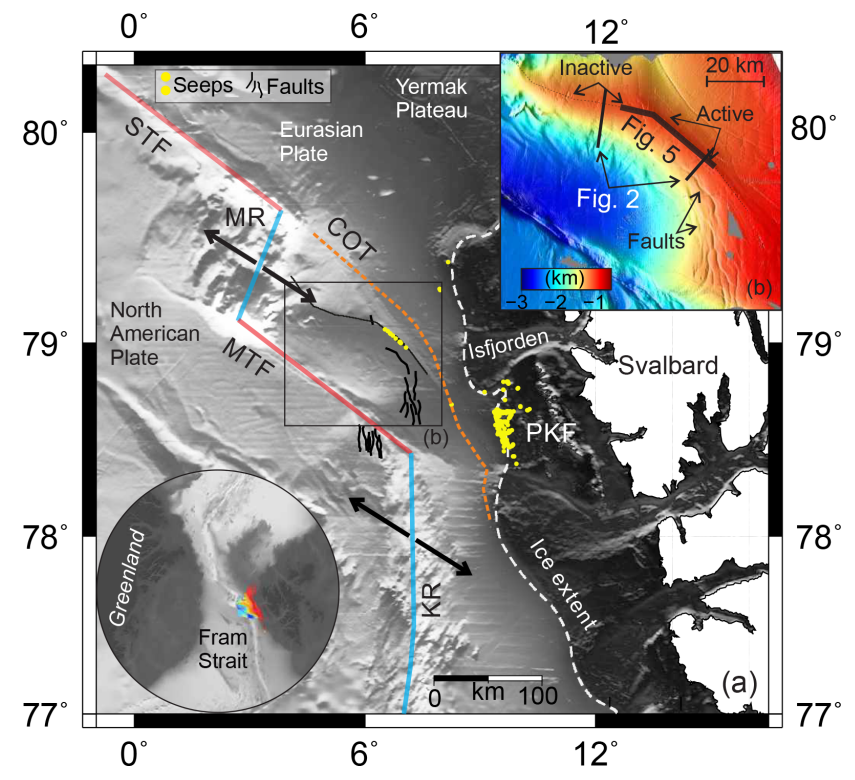

Figure 1. (a) International Bathymetric Chart of the Arctic Ocean (IBCAO) showing the geometry of mid-ocean ridges offshore of the western Svalbard margin. (b) High-resolution bathymetry along the Vestnesa Ridge (UiT, R/V Helmer Hanssen multi-beam system). Seafloor pockmarks are observed along the entire ridge, but acoustic flares are restricted to the eastern segment. PKF refers to Prins Karls Forland, STF refers to the Spitsbergen Transform Fault, MR refers to Molloy Ridge, MTF refers to the Molloy Transform Fault, $\mathrm{KR}$ refers to Knipovich Ridge, COT is the continental-oceanic transition (Engen et al., 2008), and the ice-sheet extent is represented by the dashed line (Patton et al., 2016).

curring episodically for millions of years (e.g. Judd and Hovland, 2009), but there is a poor understanding of what forces it.

Present-day seepage is identified as acoustic flares in the water column that commonly originate at seafloor depressions (e.g. Chand et al., 2012; Salomatin and Yusupov, 2011; Skarke et al., 2014; Smith et al., 2014; Westbrook et al., 2009), while authigenic carbonate mounds are used as indicators of longer-term seepage activity (e.g. Judd and Hovland, 2009). Seepage at the theoretical upstream termination of the gas hydrate stability zone (GHSZ) (i.e. coinciding with the shelf edge) at different continental margins, has been explained by temperature driven gas hydrate dissociation (e.g. Skarke et al., 2014; Westbrook et al., 2009). On formerly glaciated regions off Svalbard and in the Barents Sea, active seepage has been explained by gas hydrate dissociation either due to pressure changes resulting from the retreat of the ice sheet (e.g. Portnov et al., 2016; Andreassen et al., 2017) or to post-glacial uplift (Wallmann et al., 2018).

Across the western Svalbard margin, active seepage extends beyond the shelf break and the region formerly covered by ice. As a matter of fact, active seepage sites have been identified from inside Isfjorden (Roy et al., 2014) to water depths of $\sim 1200 \mathrm{~m}$ (Smith et al., 2014), where the Vestnesa Ridge hosts a perennially stable gas hydrate system $>50 \mathrm{~km}$ seaward from the ice-sheet grounding line. The Vestnesa Ridge is a NW-SE oriented contourite deposit located between the northward termination of the Knipovich Ridge and the eastern flank of the Molloy spreading ridge in the Fram Strait (Fig. 1). Seafloor pockmarks along the Vestnesa Ridge, first documented by Vogt et al. (1994), exist along the entire ridge. However, acoustic flares have been observed to originate exclusively at large pockmarks located on the eastern part of the sedimentary ridge (Figs. 2, 3). Thus, a clear increase in seepage activity towards the easternmost part of the ridge is evident from multiple-year water-column acoustic surveys (Petersen et al., 2010; Bünz et al., 2012; Plaza-Faverola et al., 2017; Smith et al., 2014). In this paper, we use the terminology "active" and "inactive" to differentiate between sites with and without documented acoustic flares. Even though methane advection and methanogenesis are likely to be active processes along the entire Vestnesa Ridge, the presence of inactive pockmarks adjacent to a zone of active seepage raises questions regarding what controls temporal and spatial variations in seepage activity along the ridge.

Plaza-Faverola et al. (2015) documented seismic differences in the orientation and type of faulting along the ridge and showed a link between the distribution of gas chimneys and faults. They hypothesized that seepage activity may be explained by spatial variation in the tectonic stress field across the margin (Plaza-Faverola et al., 2015). However, the state of stress across Arctic passive margins has not been investigated. The total state of stress at formerly glaciated continental margins can be the result of diverse factors including bathymetry and sub-surface density contrasts, subsidence due to glacial or sedimentary loading and lithospheric cooling, in addition to ridge-push forces (Fejerskov and Lindholm, 2000; Lindholm et al., 2000; Olesen et al., 2013; Stein et al., 1989; Grunnaleite et al., 2009).

The interaction between the above-mentioned factors renders modelling of the total state of stress a complex problem that has not yet been tackled. In this study, we focus exclusively on the potential contribution of oblique spreading at the Molloy and the Knipovich ridges to the total state of stress along the Vestnesa Ridge and undertake a qualitative analysis of how stress generated by mid-ocean ridge spreading may influence near-surface faulting and associated seepage activity. The study of the effect of ridge-push forces on near-surface deformation across the western Svalbard margin contributes to the current debate about neotectonism and stress field variations across passive margins (Olesen et al., 2013; Salomon et al., 2015). It also has implications for understanding the mechanisms that control seepage at continental margins globally. Splay-faults are found to drive fluid migration at subduction margins and to sustain shallow gas accumulations and seepage (e.g. PlazaFaverola et al., 2016; Minshull and White, 1989; Moore and 
Vrolijk, 1992; Crutchley et al., 2013); furthermore, the relationship between fault kinematics and fluid migration, in particular, has been documented at accretionary margins where earthquake-induced seafloor seepage has been observed (e.g. Geersen et al., 2016). So far, information about the presentday stress regime in the Fram Strait has been limited to largescale lithospheric density models (Schiffer et al., 2018) and a number of stress vectors from earthquake focal mechanisms along the mid-Atlantic plate boundary (Heidbach et al., 2016). Our study provides a first-order assessment of how stresses from slow spreading mid-ocean ridges may be influencing the kinematics of near-surface faults and associated seepage activity across an Arctic passive margin.

\section{Structural and stratigraphic setting}

In the Fram Strait, sedimentary basins are within tens of kilometres from ultra-slow spreading Arctic mid-ocean ridges (Fig. 1). The opening of the Fram Strait was initiated $33 \mathrm{Myr}$ ago and evolved as a result of slow spreading of the Molloy and Knipovich ridges (Engen et al., 2008). An important transpressional event deformed the sedimentary sequences off western Svalbard, resulting in folds and thrust belts, during the Paleocene-Eocene dextral movement of Spitsbergen with respect to Greenland. Transpression stopped in the early Oligocene when the tectonic regime became dominated by extension (Myhre and Eldholm, 1988). The circulation of deep water masses through the Fram Strait started during the Miocene, ca. 17-10 Myr ago (Jakobsson et al., 2007; Ehlers and Jokat, 2009), and established the environmental conditions for the evolution of bottom current-driven sedimentary drifts (Eiken and Hinz, 1993; Johnson et al., 2015). It has been suggested that the opening of the northern NorwegianGreenland Sea was initiated by the northward propagation of the Knipovich Ridge into the ancient Spitsbergen shear zone (Crane et al., 1991).

The continental crust beneath the western coast of Svalbard thins towards the Hornsund Fault zone indicating extension following the opening of the Greenland Sea (Faleide et al., 1991). Late Miocene and Pliocene sedimentation, driven by bottom currents, resulted in the formation of the ca. $100 \mathrm{~km}$ long Vestnesa Ridge between the shelf break off western Svalbard and oceanic crust highs at the eastern flank of the Molloy mid-ocean ridge (Eiken and Hinz, 1993; Vogt et al., 1994). The sedimentary ridge is oriented parallel to the Molloy Transform Fault and its crest experiences a change in morphology from narrow on the eastern segment to broader on the western Vestnesa Ridge segment (Fig. 2). The exact location of the continental-ocean transition remains uncertain (Eldholm et al., 1987), but it is inferred to be near the transition from the eastern to the western segments (Engen et al., 2008).

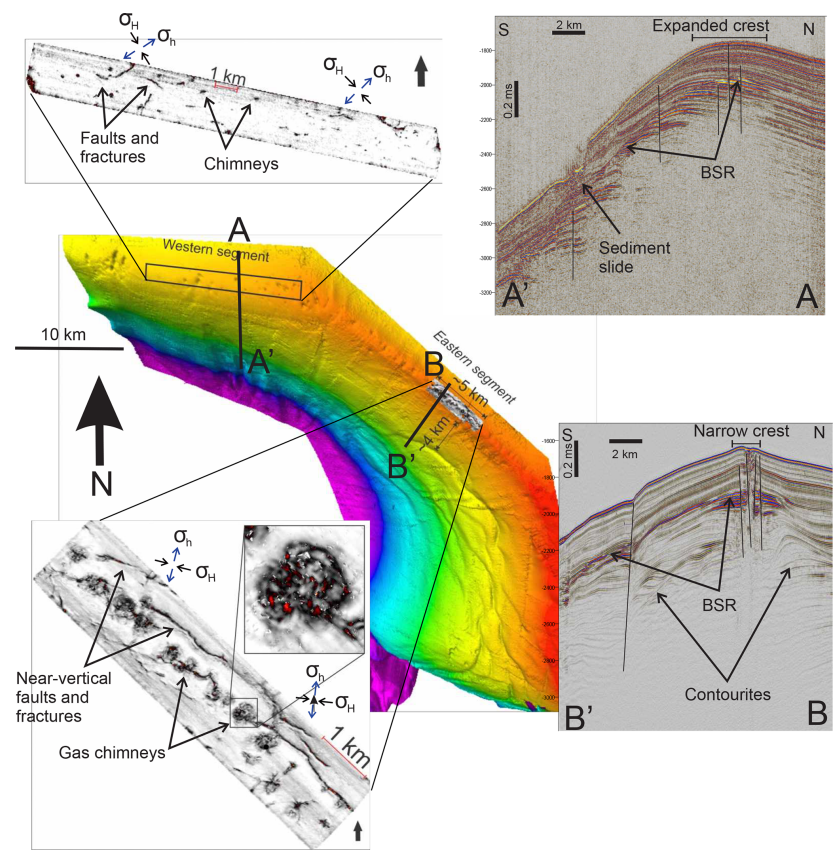

Figure 2. Composite figure with bathymetry and variance maps from 3-D seismic data along the eastern and the western Vestnesa Ridge segments (modified from Plaza-Faverola et al., 2015). The orientation of the maximum compressive horizontal stress $\left(\sigma_{\mathrm{H}}\right)$ and minimum horizontal stress $\left(\sigma_{\mathrm{h}}\right)$ predicted by the model are projected for comparison with the orientation of fault segments. Notice the favourable orientation for opening to fluids on the eastern Vestnesa Ridge segment. Two 2-D seismic transects (A-A' - Bünz et al., 2012 and B-B' - Johnson et al., 2015) illustrate the morphological difference of the crest of the Vestnesa Ridge (i.e. narrow vs. extended) which are believed to be determined by bottom current dominated deposition and erosion (Eiken and Hinz, 1993). BSR refers to bottom simulating reflector.

The total sedimentary thickness along the Vestnesa Ridge remains unconstrained. Based on one available regional seismic profile it can be inferred that the ridge is $>5 \mathrm{~km}$ thick in places (Eiken and Hinz, 1993). It has been divided into three main stratigraphic units (Eiken and Hinz, 1993; Hustoft, 2009): the deepest sequence, YP1, consists of syn-rift and post-rift sediments deposited directly on the oceanic crust; YP2 consists of contourites; and YP3, corresponding to the onset of Pleistocene glaciations (ca. 2.7 Myr ago) (Mattingsdal et al., 2014), is dominated by glaciomarine contourites and a mix of turbidites in regions close to the shelf break. The effect of ice-sheet dynamics on the western Svalbard margin (Patton et al., 2016; Knies et al., 2009) has influenced the stratigraphy, and most likely the morphology, of the Vestnesa Ridge and adjacent sedimentary basins. In this Arctic region, glaciations are believed to have started even earlier than $5 \mathrm{Myr}$ ago. The local intensification of glaciations is inferred to have started ca. 2.7 Myr ago (e.g. Faleide et al., 1996; Mattingsdal et al., 2014). Strong climatic fluctuations characterized by intercalating colder, intense glaciations with 
warmer and longer interglacials, dominated the last ca. $1 \mathrm{Myr}$ (e.g. Jansen et al., 1990; Jansen and Sjøholm, 1991).

\section{Seismic data}

Faults and fluid flow related features along the Vestnesa Ridge are described by several authors (Bünz et al., 2012; Hustoft, 2009; Petersen et al., 2010; Plaza-Faverola et al., 2015, 2017). Two 3-D high-resolution seismic data sets acquired on the western and the eastern regions of Vestnesa Ridge (Fig. 2), respectively, and one 2-D seismic line acquired along the entire Vestnesa Ridge extent have been particularly useful in the description of the structures along the ridge (Fig. 2). These data have been previously used for the investigation of the bottom simulating reflection dynamics (i.e. the seismic indicator of the base of the gas hydrate stability zone) (Plaza-Faverola et al., 2017) and documentation of gas chimneys and faults in the region (Petersen et al., 2010; Plaza-Faverola et al., 2015; Bünz et al., 2012). The 3-D seismic data were acquired on board R/V Helmer Hanssen using the high-resolution P-Cable system (Planke et al., 2009). The 2-D lines were also collected connecting four streamers from the P-Cable system for 2-D acquisition. Final lateral resolution of the 3-D data sets is given by a bin size of $6.25 \times 6.25 \mathrm{~m}^{2}$, and the vertical resolution is $>3 \mathrm{~m}$ with a dominant frequency of $130 \mathrm{~Hz}$. Details about acquisition and processing can be found in Petersen et al. (2010) and Plaza-Faverola et al. (2015). For the 2-D survey the dominant frequency was $\sim 80 \mathrm{~Hz}$ resulting in a vertical resolution $>4.5 \mathrm{~m}$ (assumed as $\lambda / 4$ with an acoustic velocity in water of $1469 \mathrm{~m} \mathrm{~s}^{-1}$ given by CTD data; Plaza-Faverola et al., 2017).

\section{The modelling approach}

The modelling carried out in this study deals exclusively with tectonic stress due to ridge push. We use the approach by Keiding et al. (2009) based on the analytical solutions derived by Okada (1985), to model the plate motion and tectonic stress field due to spreading along the Molloy and Knipovich ridges.

The Okada model and our derivation of the stress field from it is described in more detail in Appendix A. The Molloy and Knipovich ridges are modelled as rectangular planes with opening and transform motion in a flat Earth model with elastic, homogeneous, isotropic rheology (Fig. A1 in Appendix). Each rectangular plane is defined by 10 model parameters used to approximate the location, geometry, and deformation of the spreading ridges (Okada, 1985; see Supplement Table S1). The locations of the two spreading ridges were constrained from bathymetry maps (Fig. 1). The two spreading ridges are assumed to have continuous, symmetric deformation below the brittle-ductile transition, with a half spreading rate of $7 \mathrm{~mm} \mathrm{yr}^{-1}$ and a spreading direction of $\mathrm{N} 125^{\circ} \mathrm{E}$, according to recent plate motion models (DeMets et al., 2010). Because the spreading direction is not perpendicular to the trends of the spreading ridges, this results in both opening and right-lateral motion; that is, oblique spreading on the Molloy and Knipovich ridges. The Molloy Transform Fault, which connects the two spreading ridges, trends $\mathrm{N} 133^{\circ} \mathrm{E}$; thus, a spreading direction of $\mathrm{N} 125^{\circ} \mathrm{E}$ implies extension across the transform zone. We use a depth of $10 \mathrm{~km}$ for the brittle-ductile transition and $900 \mathrm{~km}$ for the lower boundary of the deforming planes, to avoid boundary effects. For the elastic rheology, we assume typical crustal values of Poisson's ratio $=0.25$ and shear modulus $=30 \mathrm{GPa}$ (Turcotte and Schubert, 2002). We perform sensitivity tests for realistic variations in (1) model geometry, (2) spreading direction, (3) depth of the brittle-ductile transition, and (4) Poisson's ratio (Supplement). Variations in shear modulus, e.g. reflecting differences in elastic parameters of crust and sediments, would not influence the results, because we do not consider the magnitude of the stresses.

Asymmetric spreading has been postulated for the Knipovich Ridge based on heat flow data (Crane et al., 1991), and for other ultra-slow spreading ridges based on magnetic data (e.g. Gaina et al., 2015). However, the evidence for asymmetry along the Knipovich Ridge remains inconclusive and debatable in terms, for example, of the relative speeds suggested for the North American (faster) and the Eurasian (slower) plates (Crane et al., 1991; Morgan, 1981; Vogt et al., 1994). This reflects that the magnetic data currently available from the western Svalbard margin is not of a quality that allows for an assessment of possible asymmetry of the spreading in the Fram Strait (Nasuti and Olesen, 2014). Thus, symmetry is conveniently assumed for the purpose of the present study.

We focus on the stress field in the upper part of the crust (where the GHSZ is) and characterize the stress regime based on the relationship between the horizontal and vertical stresses. We refer to the stresses as $\sigma_{\mathrm{v}}$ (vertical stress), $\sigma_{\mathrm{H}}$ (maximum horizontal stress), and $\sigma_{\mathrm{h}}$ (minimum horizontal stress), where compressive stress is positive (Zoback and Zoback, 2002). A tensile stress regime $\left(\sigma_{\mathrm{v}}>\sigma_{\mathrm{H}}>\sigma_{\mathrm{h}}\right)$ favours the opening of steep faults that can provide pathways for fluids. Favourable orientation of stresses with respect to existing faults and/or pore-fluid pressures increasing beyond hydrostatic pressures are additional conditions that lead to the opening for fluids under strike-slip $\left(\sigma_{\mathrm{H}}>\sigma_{\mathrm{v}}>\sigma_{\mathrm{h}}\right)$ and compressive $\left(\sigma_{\mathrm{H}}>\sigma_{\mathrm{h}}>\sigma_{\mathrm{v}}\right)$ regimes (e.g. Grauls and Baleix, 1994). 


\section{Results}

\subsection{Predicted type and orientation of stress fields due to oblique spreading at the Molloy and the Knipovich ridges}

The model predicts zones of tensile stress near the spreading ridges, and strike-slip at larger distances from the ridges. An unexpected pattern of tensile stress arises from the northward termination and the southward termination of the Knipovich and Molloy ridges respectively (Fig. 3). The zone of tensile stress that extends northward from the Knipovich Ridge, encompasses the eastern part of the Vestnesa Ridge. The western Vestnesa Ridge, in comparison, lies entirely in a zone of strike-slip stress (Fig. 3). The sensitivity tests show that the tensile stress zone is a robust feature of the model, meaning that variations in the parameters result in a change of the extent and shape of the tensile zone but the zone remains in place (Supplement). It appears that the tensile zone is a result of the interference of the stress from the two spreading ridges. To illustrate this, we ran the model for the Molloy Ridge and the Knipovich Ridge independently. In the model with Knipovich Ridge alone, a large tensile zone extends north-east from the ridge's northern end, covering only the easternmost corner of Vestnesa Ridge (Fig. 4). Under the influence of the strike-slip field from the Molloy Ridge, this zone is deflected and split into two lobes, one of which extends to the eastern Vestnesa Ridge segment.

To investigate the geometric relationship between the predicted stress field and mapped faults, we calculated the orientations of maximum compressive horizontal stress (Lund and Townend, 2007). The maximum horizontal stresses $\left(\sigma_{\mathrm{H}}\right)$ approximately align with the spreading axes within the tensile regime and are perpendicular to the axes within the strike-slip regime (Fig. 3). Spreading along the Molloy Ridge causes a NW-SE orientation of the maximum compressive stress along most of the Vestnesa Ridge, except for the eastern segment where the influence of the Knipovich Ridge results in a rotation of the stress towards the E-W (Fig. 3).

The simplifying assumptions involved in our model imply that the calculated stresses in the upper crust are unconstrained to a certain degree. However, the predicted stress directions are in general agreement with other models of plate tectonic forces (e.g. Gölke and Coblentz, 1996; Naliboff et al., 2012). In addition, Árnadóttir et al. (2009) demonstrated that the deformation field from the complex plate boundary in Iceland could be modelled using Okada's model. More importantly, a comparison of the predicted strike-slip and tensile stress fields from plate spreading and observed earthquake focal mechanisms shows an excellent agreement, both with regards to stress regime and the orientation of the maximum compressive stress. The earthquake focal mechanisms are mostly normal along the spreading ridges and strike-slip along the transform faults, and the focal mechanism pressure axes align nicely with the predicted directions of max-

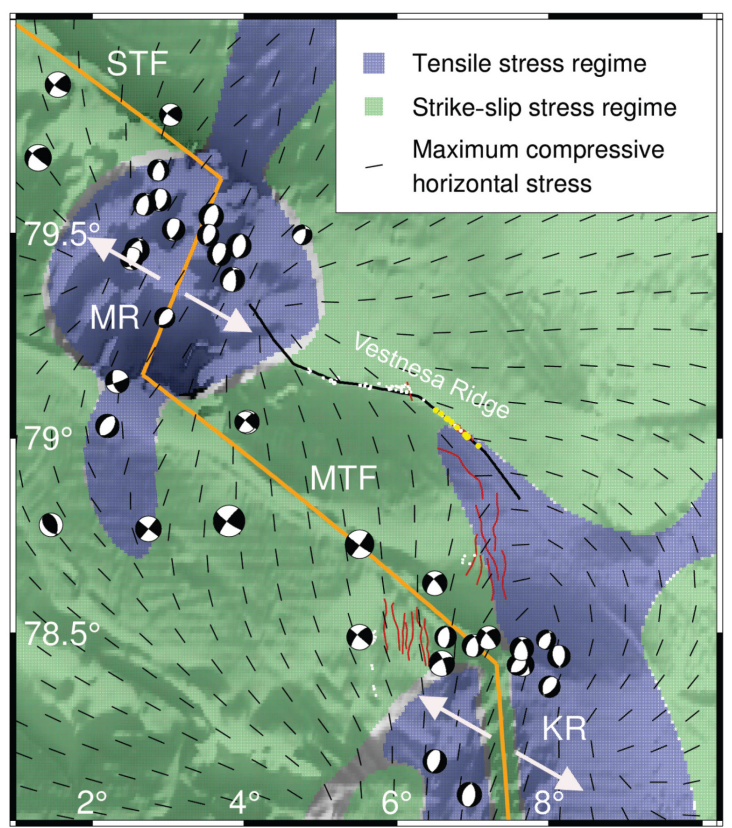

Figure 3. Modelled upper crustal tectonic stress field (blue - tensile and green - strike-slip regime) and stress orientations, due to oblique spreading at the Molloy Ridge (MR) and the Knipovich Ridge (KR). The outline of a seismic line (Plaza-Faverola et al., 2017) is projected as a reference for the crest of the Vestnesa Ridge. Red lines are faults, yellow dots are seeps, and white circles are pockmarks where no acoustic flares have been documented. STF refers to the Spitsbergen Transform Fault, and MTF refers to the Molloy Transform Fault. The focal mechanisms are from the ISC online bulletin (http://www.isc.ac.uk, last access: December 2016).

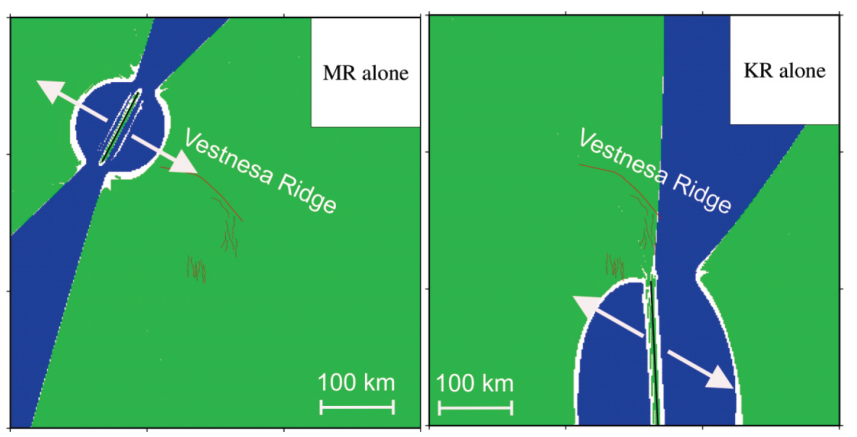

Figure 4. Stress field resulting from model runs with Molloy Ridge and Knipovich Ridge, respectively: tensile stress field (blue); strikeslip stress field (green).

imum compressive stress (Fig. 3). The good agreement between Okada's model and other modelling approaches as well as between the resulting stresses and focal mechanisms in the area indicates that the model, despite the simplicity of its assumptions, provides a correct first-order prediction of the orientation and type of the stress field in the upper crust (other possible sources of stress in the region will be 
discussed in more detail in Sect. 6.1). The degree to which the crustal stresses are transferred to the sedimentary successions of the Vestnesa Ridge remains an open question. For compacted stratigraphic formations in the Norwegian Sea, a comparison of shallow in situ stress measurements and deeper observations from earthquake focal mechanisms indicates that the stress field is homogeneous in direction over a large depth range (Fejerskov and Lindholm, 2000). However, for an overburden constituted of Quaternary sediments the stress coupling between the crust and the near-surface depends on the shear strength of the sediments. The upper $200 \mathrm{~m}$ of hemipelagic sediment along the Vestnesa Ridge are relatively young ( $<2 \mathrm{Myr}$ old) and the degree of sediment consolidation remains uninvestigated. Nevertheless, the fact that a large number of faults extend several hundred metres through the sediments suggests that the compaction of the sediments has been large enough to build up some amount of shear strength. Geotechnical studies from different continental margins indicate that deep marine sediments can experience high compressibility due to homogeneity in the grain structure (i.e. large areas made of a single type of sediment), providing favourable conditions for shear failure (Urlaub et al., 2015; DeVore and Sawyer, 2016). Therefore, we consider it possible that the upper sedimentary column along the Vestnesa Ridge has been deformed by tectonic stress.

\subsection{Distribution of faults and seepage activity along the Vestnesa Ridge with respect to modelled tectonic stress}

High-resolution 3-D seismic data collected on the eastern Vestnesa Ridge revealed sub-seabed NW-SE oriented, nearvertical faults with a small normal throw ( $<10 \mathrm{~m}$; Fig. 5). In this part of the Vestnesa Ridge, gas chimneys and seafloor pockmarks are ca. $500 \mathrm{~m}$ in diameter. On structural maps extracted along surfaces within the GHSZ gas chimneys project over fault planes or at the intersection between fractures (Figs. 2 and 3c). A set of N-S to NNE-SSE trending faults outcrop at the seafloor in a narrow zone between the Vestnesa Ridge and the northern termination of the Knipovich Ridge (Figs. 1 and 2). These faults have been suggested to indicate ongoing northward propagation of the Knipovich rift system (Crane et al., 2001; Vanneste et al., 2005). The NW-SE oriented sub-seabed faults and fractures at the crest of the Vestnesa Ridge could be genetically associated with these outcropping faults (Plaza-Faverola et al., 2015; Fig. 2).

Most of the outcropping N-S to NNE-SSE oriented faults north of the Knipovich Ridge and the sub-seafloor NWSE oriented faults on the eastern Vestnesa Ridge are located within the zone of modelled tensile regime that extends northward from the Knipovich Ridge (Fig. 3). The orientation of $\sigma_{\mathrm{H}}$ rotates from being perpendicular to the Molloy Ridge near sub-seafloor faults at the eastern Vestnesa Ridge, to being more perpendicular to the Knipovich Ridge in places within the tensile zone (Fig. 3). Interestingly, doc-

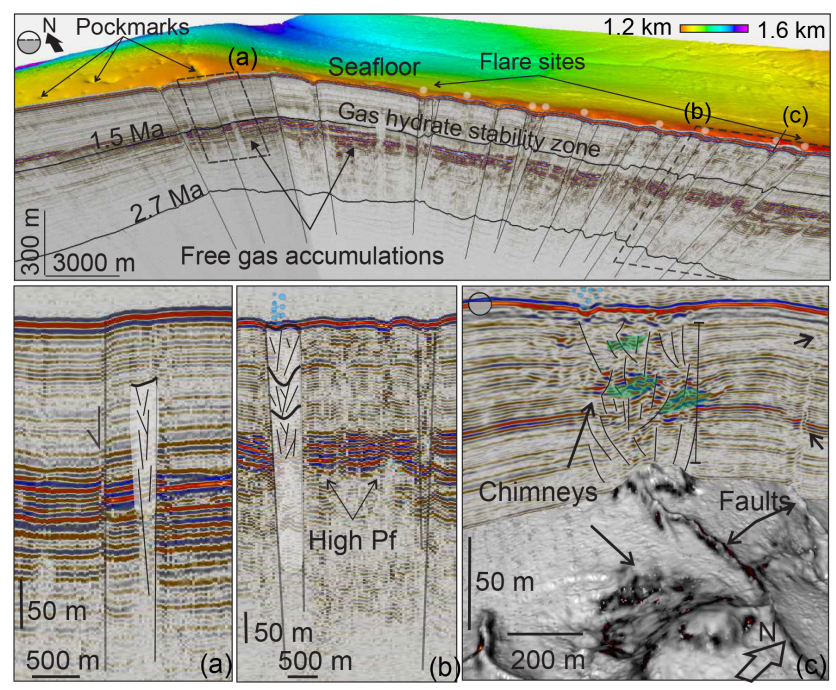

Figure 5. Integrated seismic and bathymetry image of the gas hydrate system along the Vestnesa Ridge. (a) Outcropping N-S oriented fault located at the transition from the region where acoustic flares have been documented to the region where no flares have been observed; (b) gas chimneys with associated acoustic flare and inferred high pore-fluid pressure (Pf) zone at the base of the gas hydrate stability zone; (c) gas chimney associated with faults and faults extending to near-surface strata without being associated with chimneys. The same variance map as in Fig. 2 is projected at the depth where the map was extracted along a surface interpreted on the 3-D seismic volume. Green patches represent interpreted zones of buried authigenic carbonate that can activate a self-sealing mechanism leading to hydrofracturing and chimney development (PlazaFaverola et al., 2015).

umented acoustic flares along the Vestnesa Ridge are also located within the zone of modelled tensile stress regime (Fig. 3). The match between the extent of the modelled tensile regime and the active region of pockmarks is not exact: pockmarks with acoustic flares exist a few kilometres westward from the termination of the tensile zone (Fig. 3). However, the agreement is striking from a regional point of view. Some of the outcropping faults north of the Knipovich Ridge and south of the Molloy transform fault appear to be located outside the modelled tensile zone (Figs. 3, S1-S4 in the Supplement). Inactive pockmarks (i.e. no acoustic flares have been observed during several visits to the area) are visible on high-resolution bathymetry maps over these faulted regions (Dumke et al., 2016; Hustoft et al., 2009; Johnson et al., 2015; Waghorn et al., 2018).

In a similar high-resolution 3-D seismic data set from the western Vestnesa Ridge the faults have different characteristics compared to those of the eastern segment. In this part of the ridge gas chimneys are narrower, buried pockmarks are stacked more vertically than the chimneys towards the east, and it is possible to recognize more faults reaching the present-day seafloor (Plaza-Faverola et al., 2015). Fault segments are more randomly oriented with a tendency toward 
WNW-ESE and E-W orientations (Fig. 2). These structures coincide with a modelled strike-slip stress regime with $\sigma_{\mathrm{H}}$ oriented nearly perpendicular to the Molloy Ridge (Fig. 3).

\section{Discussion}

The striking coincidence between the spatial variation in modelled stress regimes and the pattern of faulting and seepage activity along the Vestnesa Ridge leads to the discussion of whether tectonic stresses resulting from plate spreading at the Molloy and the Knipovich ridges have the potential to influence near-surface deformation and fluid dynamics in the study area. We first discuss the modelling results in the context of the total state of stress across passive margins and the extent to which regional stresses can influence near-surface deformation. Assuming that tectonic stress can potentially influence near-surface deformation, we then discuss the effect that the modelled stress fields would have on pre-existing faults and associated fluid migration. Finally, we propose a model to explain seepage evolution along the Vestnesa Ridge coupled to stress field variations. We close the discussion with a note on the implications of the present study with respect to understanding near-surface fluid dynamics across passive margins globally.

\subsection{Modelled stress in the context of the state of stress along the Vestnesa Ridge}

In this study we focused exclusively on modelling the type and orientation of stresses potentially generated by spreading at the Molloy and Knipovich ridges. Other sources of stress have been disregarded thus far. Hence, the modelled stress field documented in this study cannot be considered as a representation of the total stress field in the region. Modelling studies from Atlantic-type passive margins, suggest that from all the possible sources of stress across passive margins (i.e. sediment loading, glacial flexure, spatial density contrasts, and ridge push as well as basal drag forces) sediment loading (assuming elastic deformation) appears to be the mechanism with the potential to generate the largest magnitudes of stresses across passive margins (Stein et al., 1989; Turcotte et al., 1977). However, stress information derived from seismological and in situ data (Fjeldskaar and Amantov, 2018; Grunnaleite et al., 2009; Lindholm et al., 2000; Olesen et al., 2013) and palaeo-stress field analyses based on dip and azimuth of fault planes (Salomon et al., 2015) point towards the dominant effect of ridge-push forces on the state of stress across passive continental margins. Given the proximity of the Vestnesa Ridge to the Molloy and the Knipovich ridges (Fig. 1), we argue that tectonic stress from spreading could be an important factor, perhaps even a dominant factor, controlling near-surface deformation along the Vestnesa Ridge.

The contemporary stress field across the western Svalbard passive margin is presumably the result of an inter- action between large-scale tectonic stress mechanisms (i.e. ridge push, basal drag) overprinted by regional (i.e. density contrasts, glacial related flexure, sediment loading) and local (e.g. topography, pore-fluid pressure variations, faulting) mechanisms. In the concrete case of the Vestnesa Ridge, a change in the faulting pattern, the distribution of shallow gas and gas hydrates, and differences in the topographic characteristics of the ridge crest (Figs. 2 and 5), are all factors likely to induce local changes in the degree of compaction and in near-surface stress. We discuss how local stress-generating mechanisms may interact with tectonic forcing to control fluid dynamics and seepage in the following sections.

The Vestnesa sedimentary Ridge sits over relatively young oceanic crust, <19 Myr old (Eiken and Hinz, 1993; Hustoft et al., 2009). The oceanic-continental transition is not well constrained but its inferred location crosses the Vestnesa Ridge at its easternmost end (Engen et al., 2008; Hustoft et al., 2009). This is a zone prone to flexural subsidence due to cooling during the evolution of the margin, and the oceanic crust may have experienced syn-sedimentary subsidence focused around the oceanic-continental transition, as suggested for Atlantic passive margins (Turcotte et al., 1977). However, syn-sedimentary subsidence would result in $\mathrm{N}-\mathrm{S}$ oriented faults (i.e. reflecting the main direction of major rift systems during basin evolution) (Faleide et al., 1991, 1996). Although one N-S oriented fault outcrops in bathymetry data at the transition from the eastern to the western Vestnesa Ridge segments (Fig. 5a), most of the sub-seabed faults and associated fluid migration features in the 3-D seismic data are NW-SE to E-W oriented (Figs. 1 and 2).

The weight of the contourite ridge over the oceanic crust may have generated additional stress on the Vestnesa Ridge. Sedimentation rates on the Vestnesa Ridge have been moderate, and are estimated to have fluctuated between 0.1 and $0.6 \mathrm{~mm}$ year $^{-1}$ since the onset of glaciations $2.7 \mathrm{Myr}$ ago (Plaza-Faverola et al., 2017; Knies et al., 2018; Mattingsdal et al., 2014). The lithology of the upper sediment along the ridge appears dominated by soft fine-grained hemipelagic clayey silt with variable concentrations of ice-rafted debris (Sztybor and Rasmussen, 2017a). Together, sedimentation rates and a high clay content would provide an ideal setting for under-compaction due to increased pore-fluid pressure (e.g. Fertl, 1976; Buchan and Smith, 1999). High porefluid pressure would lead to a decrease in the effective stress and favour shearing (Grauls and Baleix, 1994). Whether sedimentation rates allowed stress to build up through the upper strata faster than they caused relaxation at the crust (i.e. as expected for sedimentation rates larger than $1 \mathrm{~mm}$ year $^{-1}$; Stein et al., 1989), as well as what the role of gas hydrates and authigenic carbonate on the compaction history of the sediment has been remains to be investigated.

Glacial isostasy results in significant stresses associated with flexure of the lithosphere as the ice sheet advances or retreats. Present uplift rates are highest at the centre of the formerly glaciated region where the ice thickness was 
at its maximum (Fjeldskaar and Amantov, 2018). Modelled present-day uplift rates at the periphery of the Barents Sea ice sheet ranges from 0 to $-1 \mathrm{~mm}_{\text {year }}{ }^{-1}$, depending on the icesheet model used in the calculation (Auriac et al., 2016). This compares to an uplift rate of up to $9 \mathrm{~mm}$ year $^{-1}$ at the centre of the ice sheet (Auriac et al., 2016; Patton et al., 2016). Modelled glacial stresses induced by the Fennoscandian ice sheet on the mid-Norwegian margin are close to zero at present day (Lund et al., 2009; Steffen et al., 2006). By analogy, presentday stress along the Vestnesa Ridge - located $\sim 60 \mathrm{~km}$ from the shelf break - may be insignificant. It is likely that glacial stresses as far off as the Vestnesa Ridge had a more significant effect in the past, as further discussed in Sect. 6.3 and 6.4 .

Finally, ridge-push forcing has the potential to be a dominant factor on the state of stress across the western Svalbard margin as observed for Norwegian margins (Fejerskov and Lindholm, 2000; Lindholm et al., 2000). Specifically, the Vestnesa Ridge has the particularity that it is located within the expected range of maximum influence of ridgepush forces on the stress regime (Fejerskov and Lindholm, 2000) and that forces from two spreading ridges influence it from different directions (i.e. the Molloy Ridge from the west and the Knipovich Ridge from the south-east). The intriguing stress pattern appears to be caused by the interaction of the stress generated by the two spreading ridges, as described above (Sect. 5.1).

\subsection{Effect of the modelled stress fields on pre-existing faults and present-day seepage}

Bearing in mind that several factors contribute to the total state of stress at different scales across passive margins we assume that an influence on near-surface deformation by mid-ocean ridge stresses is plausible and discuss their potential effect on seepage activity. Depending on the tectonic regime, the permeability through faults and fractures may be enhanced or inhibited (e.g. Sibson, 1994; Hillis, 2001; Faulkner et al., 2010). Thus, spatial and temporal variations in the tectonic stress regime may control the transient release of gas from the seafloor over geological time as documented, for example, for $\mathrm{CO}_{2}$ analogues in the Colorado Plateau (e.g. Jung et al., 2014).

A gas hydrate system is well developed and shallow gas accumulates at the base of the GHSZ along the entire Vestnesa Ridge (Plaza-Faverola et al., 2017). Thermogenic gas accumulations at the base of the GHSZ (Fig. 5) are structurally controlled (i.e. the gas migrates towards the crest of the sedimentary ridge) and together with microbial methane this gas sustains present-day seepage activity (Bünz et al., 2012; Plaza-Faverola et al., 2017; Knies et al., 2018). However, seepage is focused and restricted. Some of the mechanisms commonly invoked to explain seepage activity across passive margins include climate related gas hydrate dissociation, tidal or seasonal sea-level changes, and pressure in- creases in shallow reservoirs due to fast sedimentation (e.g. Bünz et al., 2003; Hustoft et al., 2010; Karstens et al., 2018; Riboulot et al., 2014; Skarke et al., 2014; Berndt et al., 2014; Wallmann et al., 2018; Westbrook et al., 2009; Franek et al., 2017). While all of these mechanisms may influence seepage systems as deep as the Vestnesa Ridge (>1000 m deep; as discussed further in Sect. 6.3), they offer no explanation as to why seepage activity is more substantial within chimney sites proximal to or at fault planes and why seepage is at a minimum or stopped elsewhere along the ridge (Figs. 2, 5). Overall, the pattern of seepage activity along the Vestnesa Ridge is strikingly consistent with the modelled tectonic stress field pattern. Acoustic flares have been documented to originate from $<10 \mathrm{~m}$ broad zones (Panieri et al., 2017) within pockmarks located exclusively along faults. We suggest that these faults are favourably oriented with respect to a tectonic $\sigma_{\mathrm{H}}$ (Fig. 2) and that opening of fault segments favourably oriented with respect to the stress field is one controlling factor of present-day seepage.

Present-day seepage activity is less pronounced towards the western Vestnesa Ridge. Despite available gas trapped at the base of the GHSZ (Fig. 5) the faults are generally less favourably oriented for tensile opening (i.e. NW-SE oriented $\left.\sigma_{\mathrm{H}}\right)$ and are under a strike-slip regime (Fig. 2). The cluster of larger scale N-S to NNW-SSE trending extensional faults that outcrop at the southern slope of the Vestnesa Ridge (Figs. 1 and 2) also coincides with the zone of predicted tensile stress (Fig. 3). However, the modelled maximum compressive stress in this area is generally oblique to the fault planes, making these faults less open for gas. Interestingly, this is also a zone of pockmarks where acoustic flares have not been observed (e.g. Johnson et al., 2015; Hustoft et al., 2009; Vanneste et al., 2005). A set of N-S oriented structures south of the Molloy Transform Fault and a train of pockmarks at the crest of a ridge west of the Knipovich Ridge axis are located under a strike-slip regime with $\mathrm{N}-\mathrm{S}$ oriented $\sigma_{\mathrm{H}}$ (Fig. 3). Although gas accumulations and gas hydrates have been identified at the crest of this ridge, acoustic flares have not been documented so far (Johnson et al., 2015; Waghorn et al., 2018). We suggest that the $\mathrm{N}-\mathrm{S}$ trending faults in this region may be impermeable to fluids despite a parallel $\sigma_{\mathrm{H}}$, if the stress regime is transpressive. Transpression has been documented at different stages of the opening of the Fram Strait (Jokat et al., 2016; Myhre and Eldholm, 1988); thus, it is a plausible tectonic mechanism for holding the gas from escaping. Ongoing studies will shed light on the structural evolution of this near-surface system.

The bathymetry of the southern flank of the Vestnesa Ridge deepens from 1200 to $1600 \mathrm{~m}$ along the crest of the Vestnesa Ridge to ca. $2000 \mathrm{~m}$ near the Molloy Transform Fault (Fig. 1). Thus, the additional effect of gravitational stress on near-surface deformation and seepage in the region cannot be ruled out. In particular, although the faults at the steep slope north of the Knipovich Ridge have been suggested to reflect the northward propagation of the Knipovich 
Ridge rift system (Crane et al., 2001; Vanneste et al., 2005), it is likely that their formation was influenced by gravitational stresses. Small-scale slumps at the slope (Figs. 1 and 2) could also be evidence of gravitational forcing at the steep southern flank of the Vestnesa Ridge. However, sub-seabed faults on the eastern Vestnesa Ridge dip towards the northeast (Fig. 5c), suggesting that gravitational forcing is not necessarily influencing the behaviour of faults and current seepage activity on the eastern Vestnesa Ridge.

\subsection{Seepage evolution coupled with stress field variations}

The seepage system along the Vestnesa Ridge has been highly dynamic over geological time. Both microbial and thermogenic gas contribute to the gas hydrate and seepage system (Hong et al., 2016; Panieri et al., 2017; PlazaFaverola et al., 2017; Smith et al., 2014). Reservoir modelling shows that source rock deposited north of the Molloy Transform Fault potentially started to generate thermogenic gas $6 \mathrm{Myr}$ ago and that migrating fluids reached the Vestnesa Ridge crest at the active seepage site ca. $2 \mathrm{Myr}$ ago (Knies et al., 2018). Seepage has been occurring, episodically, at least since the onset of the Pleistocene glaciations directly through faults, and a deformation typical of gas chimneys (i.e. where periodicity is evidenced by buried pockmarks and authigenic carbonate crusts) seems to have started later (Plaza-Faverola et al., 2015). However, the periodicity of seepage events documented since the Last Glacial Maximum seems to indistinctively correlate with glacials or interglacials (Consolaro et al., 2015; Schneider et al., 2018a; Sztybor and Rasmussen, 2017b). One transient event was dated to ca. 17000 years based on the presence of a $\sim 1000$ year old methane-dependent bivalve community possibly sustained by a gas pulse through a fault or chimney (Ambrose et al., 2015). A tectonic control on the evolution of near-surface fluid flow systems and seepage along the Vestnesa Ridge is an explanation that reconciles the numerous cross-disciplinary observations in the area.

The spatial relation between gas chimneys at the crest of the ridge and fault planes (Figs. 2 and 5c) (Bünz et al., 2012; Plaza-Faverola et al., 2015) is intriguing and raises the question of whether the faulting was posterior to brecciation (fracturing) of the strata during chimney formation. Gas chimneys form by hydrofracturing generated at a zone of over-pressure in a reservoir (e.g. Karstens and Berndt, 2015; Hustoft et al., 2010 and references therein; Davies et al., 2012). From the mechanical point of view the tensile faults at the eastern Vestnesa Ridge would not be a favourable setting for the generation of hydrofracturing and chimney formation right through fault planes as observed in seismic data (Figs. 2, 5c). For gas chimneys to be the youngest features fault segments would have to become tight and impermeable at certain periods of time, allowing pore-fluid pressure, e.g. at the free gas zone beneath the GHSZ, to build up (Fig. 5); this is a plausible scenario. The faults may get locally plugged with gas hydrates and authigenic carbonate and activate a self-sealing mechanism similar to that suggested for chimneys at other margins (e.g. Hovland, 2002). A model of gas hydrate-sealed faults and an increased free gas zone underneath, has been suggested to explain seismic attenuation and velocities from an ocean bottom seismic experiment over the gas hydrate system north of the Knipovich Ridge (Madrussani et al., 2010). Nevertheless, where gas chimneys do not disturb the seismic response, fault planes are observed to extend near the seafloor (Fig. 5c). This observation suggests that the latest faulting periods may have broken through already brecciated regions connecting gas chimneys that were already in place. Both cases are consistent with the fact that acoustic flares and seepage bubbles are restricted to focused weakness zones (Panieri et al., 2017). We suggest that an interaction between pore-fluid pressure at the base of the GHSZ and tectonic stress has led to local stress field variations and controlled seepage evolution. Opening of fractures is facilitated if the minimum horizontal stress is smaller than the pore-fluid pressure $\left(p_{\mathrm{f}}\right)$, meaning that the minimum effective stress is negative $\left(\sigma_{\mathrm{h}}^{\prime}=\sigma_{\mathrm{h}}-p_{\mathrm{f}}<0\right)$ (e.g. Grauls and Baleix, 1994). Secondary permeability may increase due to the formation of tension fractures near damaged fault zones (Faulkner et al., 2010). Cycles of negative minimum effective stress and the subsequent increase in secondary permeability in a tensile stress regime can be achieved particularly easily in the near-surface region and would provide an explanation for the development of chimneys coupled to near-surface tectonic deformation. A constant input of thermogenic gas from an Eocene reservoir since at least ca. $2 \mathrm{Myr}$ ago would have contributed to localized pore-fluid pressure increases (Knies et al., 2018).

Geophysical and palaeontological data indicate that there was once more prominent seepage and active chimney development on the western Vestnesa Ridge segment (e.g. Consolaro et al., 2015; Plaza-Faverola et al., 2015; Schneider et al., 2018b). An interaction between pore-fluid pressure and tectonic stress would explain variations in the amount of seepage activity over geological time. Following the same explanation as for present-day seepage, the negative $\sigma_{\mathrm{h}}^{\prime}$ condition could have been attained anywhere along the Vestnesa Ridge in the past due to pore-fluid pressure increases at the base of the GHSZ or due to favourable stress conditions. During glacial periods, flexural stresses should have been significantly higher than at present day (Lund and Schmidt, 2011). According to recent models of glacial isostasy by the Barents Sea ice sheet during the last glacial maximum, the Vestnesa Ridge was located in a zone where subsidence could have been in the order of tens of metres (Patton et al., 2016). At other times, before and after glacial maximums, the Vestnesa Ridge was possibly located within the isostatic forebulge.

In general, it is expected that glacial-induced maximum horizontal stresses $\left(\sigma_{\mathrm{H}}\right)$ would be dominantly oriented parallel to the shelf break (Björn Lund, personal communication, 


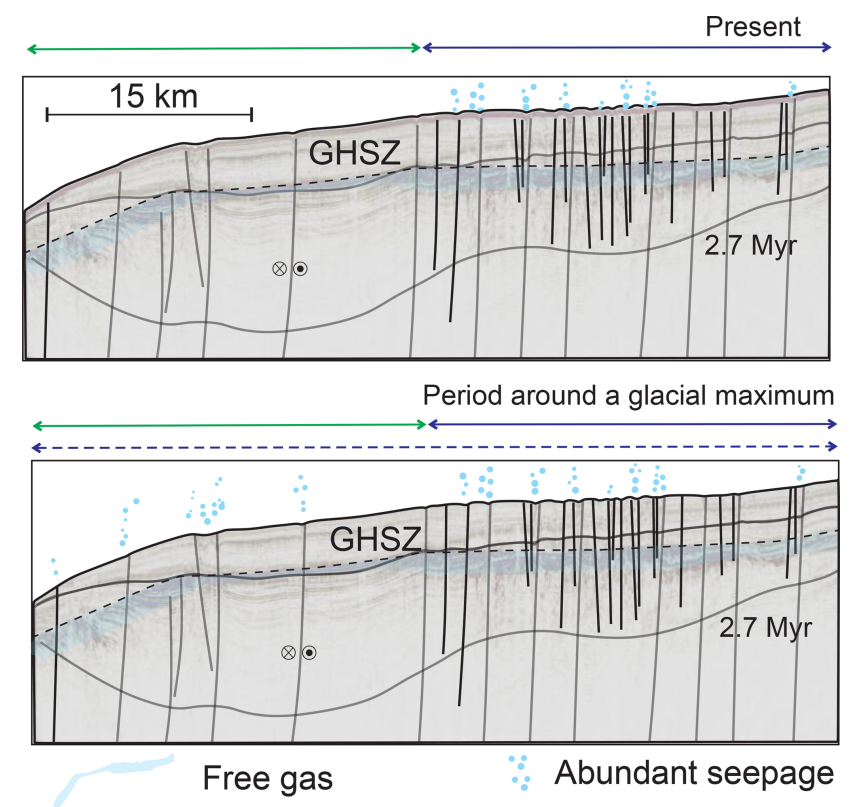

Figure 6. Conceptual model of the evolution of seepage coupled with faulting and spatial variations in the stress regime (tensile is represented using blue, and strike-slip is represented using green) along the Vestnesa Ridge, offshore of the western Svalbard margin. At present day, tensile stress from mid-ocean ridge spreading (blue solid line) favours seepage exclusively on the eastern segment of the Vestnesa Ridge. Seepage on the western Vestnesa Ridge and other regions may have been induced repeatedly since the onset of glaciations 2.7 Myr ago (Mattingsdal et al., 2014), due to tensional flexural stresses (dashed blue line) in the isostatic forebulge around the time of glacial maximums; GHSZ refers to the gas hydrate stability zone. The dashed black line follows the bottom simulating reflector which represents the base of the GHSZ.

2018; Lund et al., 2009), meaning that they would be oriented N-S in the area of the Vestnesa Ridge (Fig. 1). Such stress orientation would not favour opening for fluids along pre-exiting NW-SE oriented faults associated with seepage activity at present (i.e. $\mathrm{N}-\mathrm{S}$ oriented faults would be the more vulnerable for opening). However, it is possible that the repeated waxing and waning of the ice sheet caused a cyclic modulation of the stress field (varying magnitude and orientation), influenced the dynamics of gas accumulations, and favourably oriented faults along the Vestnesa Ridge in the past. Past glacial stresses may then provide an alternative explanation for seepage along the entire Vestnesa Ridge extent at given periods of time (Fig. 6). This explanation is in line with the correlation between seepage and glacial-interglacial events postulated for different continental margins e.g., for chimneys off the mid-Norwegian margin (Plaza-Faverola et al., 2011), the Gulf of Lion (Riboulot et al., 2014), and also along the Vestnesa Ridge (Plaza-Faverola et al., 2015; Schneider et al., 2018b).

A temporal variation in the stress field along the Vestnesa Ridge is also caused by its location on a constantly grow-

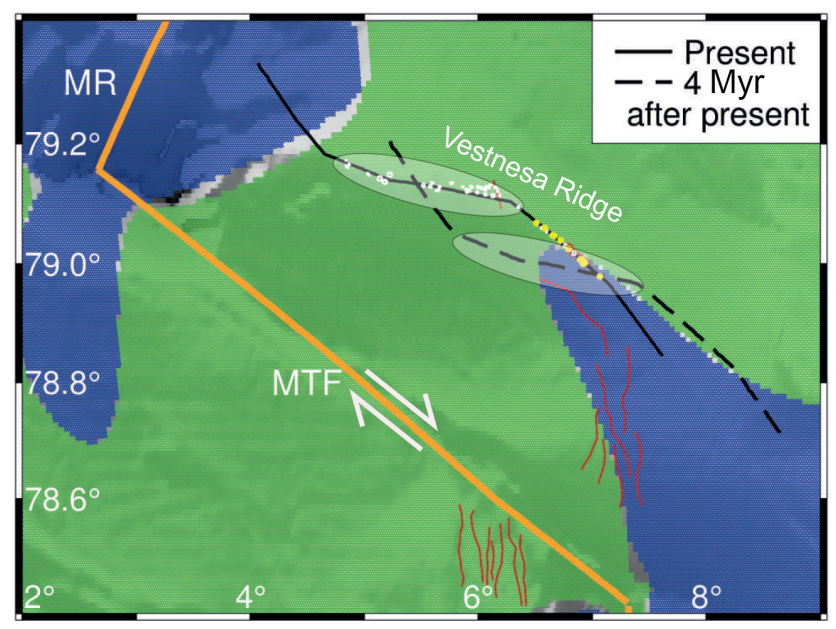

Figure 7. Stress field as in Fig. 3 showing the location of the Vestnesa Ridge at present and $4 \mathrm{Myr}$ after present, assuming a constant spreading velocity of $7 \mathrm{~mm} \mathrm{yr}^{-1}$ in the $\mathrm{N} 125^{\circ} \mathrm{E}$ direction. The same outline as in Fig. 3 is used as reference for the crest of the Vestnesa Ridge. Yellow and white dots represent pockmarks with and without documented acoustic flares, respectively.

ing plate. As the oceanic plate grows, the Vestnesa Ridge moves eastward with respect to the Molloy and Knipovich ridges, causing a westward shift in the regional stress field on the Vestnesa Ridge (Fig. 7). In future, the eastern Vestnesa Ridge may temporarily move out of the tensile zone, while the western Vestnesa Ridge moves into it (Fig. 7). This suggests that a negative effective stress and subsequent active seepage may reappear and "reactivate" pockmarks to the west of the currently active seepage zone.

\subsection{Implications for the understanding of near-surface deformation across passive margins}

Our study is a first step in the investigation of the effect of regional stress on the dynamics of near-surface fluid flow systems across passive margins. Analytical modelling of spreading at the Molloy and the Knipovich ridges shows that complex stress fields may arise from the interaction of the dynamics at plate boundaries and exert an effect across passive margins. Although the Vestnesa Ridge is a unique case study due to its remarkable proximity to the Arctic mid-ocean ridges, stresses generated by plate tectonic forces are expected to extend for thousands of kilometres (Fejerskov and Lindholm, 2000). Across a single passive margin a range of regional and local factors may result in spatial stress field variations that can explain the focusing of gas seepage at specific regions. For instance, the pervasive seepage zone west of Prins Karls Forland (PKF) on the western Svalbard margin (Fig. 1) could be under a stress regime that has been influenced by glacial rebound at a larger degree than at the Vestnesa Ridge area over geological time. Wallmann et al. (2018) suggested that post glacial uplift led to gas hydrate dissociation after the 
Last Glacial Maximum and that such gas continues to sustain seepage off PKF. Previously, several other studies have argued for a gas hydrate control on seepage in this region (e.g. Berndt et al., 2014; Portnov et al., 2016; Westbrook et al., 2009). As no gas hydrates have been found despite deep drilling (Riedel et al., 2018), the gas hydrate hypotheses remain debatable. The influence of regional stresses on sub-seabed faults suspected to underlay the seepage system (e.g. Mau et al., 2017) and shallow gas reservoirs (Knies et al., 2018) provides an alternative and previously uncontemplated explanation for seepage in this area. The interactions between tectonic stress regimes and pore-fluid pressure we propose for explaining seepage evolution along the Vestnesa Ridge may be applicable to seepage systems along other passive margins, in particular along Atlantic passive margins where leakage from hydrocarbon reservoirs is prominent (e.g. the mid-Norwegian margin, the Barents Sea, the North Sea, the north-east Greenland margin, the Mediterranean and even the Scotia Plate between Argentina and Antarctica) (e.g. Andreassen et al., 2017; Bünz et al., 2003; Hovland and Sommerville, 1985; Riboulot et al., 2014; Somoza et al., 2014; Vis, 2017). The Vestnesa Ridge case study adds a new perspective to the current debate regarding the inactivity of passive margins (Fejerskov and Lindholm, 2000; Fjeldskaar and Amantov, 2018; Lindholm et al., 2000; Olesen et al., 2013; Stein et al., 1989).

\section{Conclusions}

Analytical modelling of the stress field generated by oblique spreading at the Molloy and Knipovich ridges in the Fram Strait, suggests that spatial variations in the tectonic stress regime along the Vestnesa Ridge are plausible. Thus, midocean ridge spreading may be an important factor controlling faulting and seepage distribution in the region. Other important sources of stress such as gravitational forcing and lithospheric bending, which contribute to the actual state of stress off Svalbard, are not considered in the modelling exercise presented here. Hence, we cannot quantitatively assess whether ridge push has a dominant effect on seepage activity. However, provided a certain degree of coupling exists between crustal and near-surface deformation, it is plausible that stresses from plate spreading may affect the behaviour of Quaternary faults along the Vestnesa Ridge and exert a certain control on seepage. Our study supports a tectonic explanation for the observed seepage pattern in the region. The influence of rifting at the Knipovich Ridge, dominantly on the eastern Vestnesa Ridge, may be the key to understanding the focusing of present-day seepage activity along the ridge. The opening of faults and fractures favourably oriented with respect to principal stresses combined with a diminished effective stress in a tensile stress regime facilitates the release of gas from zones of relatively high pore-fluid pressure at the base of the gas hydrate stability zone. Mul- tiple seepage events along the entire extent of the Vestnesa Ridge, may have been induced by additional sources of stress likely associated with glacial isostasy. Future reactivation of currently dormant pockmarks or an increase in seepage activity is likely to follow the gradual westward propagation of the tensile stress zone on the Vestnesa Ridge as the Eurasian Plate drifts towards the south-east. Despite the simplifying assumptions of the analytical model approach implemented here, this study provides a first assessment of how important understanding the state of stress is for reconstructing seepage activity along passive margins.

\section{Outlook}

The effect of glacial stresses over the fluid flow system off western Svalbard will be further tested (at least for the Weichselian period) by implementing Lund et al. (2011) models using newly constrained Barents Sea ice-sheet models (e.g. Patton et al., 2016). Additional sources of stress related to topography/bathymetry should also be further investigated to gain a comprehensive assessment of the effect of the total stress field on near-surface fluid migration in the region.

Data availability. Replication data for the paper are stored at the UiT Open Research data base (https://doi.org/10.18710/QXQCUI, DataverseNO, V1). Please contact the authors for questions and additional requests. 


\section{Appendix A: Model description}

We use the analytical formulations of Okada (1985) for a finite rectangular dislocation source in elastic homogeneous isotropic half-space (Fig. A1). The dislocation source can be used to approximate deformation along planar surfaces, such as volcanic dykes (e.g. Wright et al., 2006), sills (e.g. Pedersen and Sigmundsson, 2004), faults (e.g. Massonet et al., 1993), and spreading ridges (e.g. Keiding et al., 2009). More than one dislocation can be combined to obtain more complex geometry of the source or varying deformation along a planar source. The deformation of the source can be defined as either lateral shear (strike-slip for faults), vertical shear (dip-slip at faults), or tensile opening.

The Okada model assumes flat Earth without inhomogeneities. While the flat-Earth assumption is usually adequate for regional studies (e.g. Wolf, 1984), the lateral inhomogeneities can sometimes cause a considerable effect on the deformation field (e.g. Okada, 1985). However, the dislocation model is useful as a first approximation of the problem.

At mid-ocean ridges, deformation is driven by the continuous spreading caused by gravitational stress due to the elevation of the ridges, but also basal drag and possibly slab pull. Deformation occurs continuously in the ductile part of the crust. Meanwhile, elastic strain builds in the upper, brittle part of the crust. To model this setting, the upper boundary of the dislocation source must be located at the depth of the brittle-ductile transition zone. The lower boundary of the source is set to some arbitrary large depth to avoid boundary effects.

The Okada model provides the displacements $u_{x}, u_{y}$, and $u_{z}$ (or velocities if deformation is time-dependent) at defined grid points at the surface and sub-surface. It also provides strain (or strain rates) defined as

$\varepsilon_{i j}=\frac{1}{2}\left(u_{i, j}+u_{j, i}\right)$

The stress field can then be calculated from the predicted strain rates. In homogeneous isotropic media, stress is related to strain as follows:

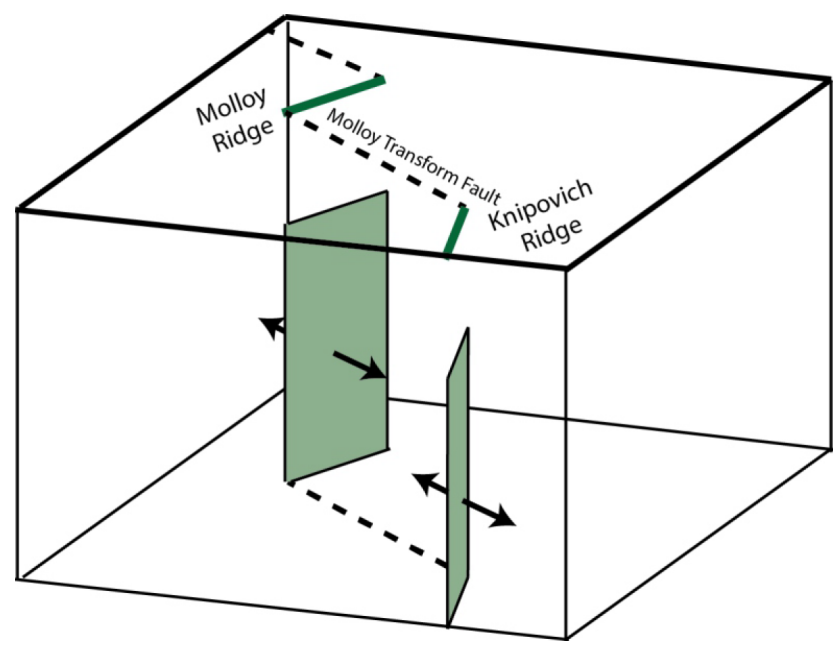

Figure A1. Extract of the model showing the location of the dislocation sources (light green) for the Molloy and Knipovich ridges. Note that the model is an infinite half-space, i.e. it has no lateral or lower boundary.

$\sigma_{i j}=\lambda \delta_{i j} \varepsilon_{k k}+2 \mu \varepsilon_{i j}$

where $\delta_{i j}$ is the Kronecker delta, $\lambda$ is Lamé's first parameter, and $\mu$ is the shear modulus. Lamé's first parameter does not have a physical meaning but is related to the shear modulus and Poisson's ratio ( $\nu)$ as $\lambda=\frac{2 \mu \nu}{1-2 \nu}$.

The absolute values of stress are generally difficult to model (e.g. Hergert and Heidbach, 2011), and is not possible with our analytical model. However, the model provides us with the orientations and relative magnitudes of the stresses. Therefore, we know the relative magnitudes between the vertical stress $\left(\sigma_{\mathrm{v}}\right)$, maximum horizontal stress $\left(\sigma_{\mathrm{H}}\right)$, and minimum horizontal stress $\left(\sigma_{\mathrm{h}}\right)$; from this, the stress regime can be defined as either tensile $\left(\sigma_{\mathrm{v}}>\sigma_{\mathrm{H}}>\sigma_{\mathrm{h}}\right)$, strike-slip $\left(\sigma_{\mathrm{H}}>\sigma_{\mathrm{v}}>\sigma_{\mathrm{h}}\right)$, or compressive $\left(\sigma_{\mathrm{H}}>\sigma_{\mathrm{h}}>\sigma_{\mathrm{v}}\right)$. 
Supplement. The supplement related to this article is available online at: https://doi.org/10.5194/se-10-79-2019-supplement.

Author contributions. APF conceived the idea for this paper and was responsible for the seismic data processing and interpretation. MK carried out the tectonic modelling. The paper is the result of the integrated work of both authors.

Competing interests. The authors declare that they have no conflict of interest.

Acknowledgements. This research is part of the Centre for Arctic Gas Hydrate, Environment and Climate (CAGE) supported by the Research Council of Norway through its Centres of Excellence funding scheme grant no. 223259. Marie Keiding is supported by the NEONOR2 project at the Geological Survey of Norway. Special thanks to Björn Lund, Peter Schmidt, Henry Patton, and Alun Hubbard for their interest in the present project and constructive discussions about isostasy and glacial stresses. We are thankful to various reviewers who have significantly contributed to the improvement of the paper. Seismic data are archived at CAGE Centre for Arctic Gas Hydrate, Environment and Climate, Troms $\varnothing$, Norway and can be made available upon request from Andreia Plaza-Faverola. Modelled stresses can be made available upon request from Marie Keiding.

Edited by: Federico Rossetti

Reviewed by: five anonymous referees

\section{References}

Ambrose, W. G., Panieri, G., Schneider, A., Plaza-Faverola, A., Carroll, M. L., Åström, E. K., Locke, W. L., and Carroll, J.: Bivalve shell horizons in seafloor pockmarks of the last glacialinterglacial transition: a thousand years of methane emissions in the Arctic Ocean, Geochem. Geophys. Geosys., 16, 4108-4129, 2015.

Andreassen, K., Hubbard, A., Winsborrow, M., Patton, H., Vadakkepuliyambatta, S., Plaza-Faverola, A., Gudlaugsson, E., Serov, P., Deryabin, A., and Mattingsdal, R.: Massive blow-out craters formed by hydrate-controlled methane expulsion from the Arctic seafloor, Science, 356, 948-953, 2017.

Árnadóttir, T., Lund, B., Jiang, W., Geirsson, H., Björnsson, H., Einarsson, P., and Sigurdsson, T.: Glacial rebound and plate spreading: results from the first countrywide GPS observations in Iceland, Geophys. J. Int., 177, 691-716, 2009.

Auriac, A., Whitehouse, P., Bentley, M., Patton, H., Lloyd, J., and Hubbard, A.: Glacial isostatic adjustment associated with the Barents Sea ice sheet: a modelling inter-comparison, Quaternary Sci. Rev., 147, 122-135, 2016.

Berndt, C., Feseker, T., Treude, T., Krastel, S., Liebetrau, V., Niemann, H., Bertics, V. J., Dumke, I., Dünnbier, K., and Ferré, B.: Temporal constraints on hydrate-controlled methane seepage off Svalbard, Science, 343, 284-287, 2014.
Buchan, S. and Smith, D. T.: Deep-sea sediment compression curves: Some controlling factors, spurious overconsolidation, predictions, and geophysical reproduction, Mar. Georesour. Geotec., 17, 65-81, https://doi.org/10.1080/106411999274016, 1999.

Bünz, S., Mienert, J., and Berndt, C.: Geological controls on the Storegga gas-hydrate system of the mid-Norwegian continental margin, Earth Planet. Sc. Lett., 209, 291-307, 2003.

Bünz, S., Polyanov, S., Vadakkepuliyambatta, S., Consolaro, C., and Mienert, J.: Active gas venting through hydrate-bearing sediments on the Vestnesa Ridge, offshore W-Svalbard, Mar. Geol., https://doi.org/10.1016/j.margeo.2012.09.012, 2012.

Chand, S., Thorsnes, T., Rise, L., Brunstad, H., Stoddart, D., Bøe, R., Lågstad, P., and Svolsbru, T.: Multiple episodes of fluid flow in the SW Barents Sea (Loppa High) evidenced by gas flares, pockmarks and gas hydrate accumulation, Earth Planet. Sc. Lett., 331, 305-314, 2012.

Consolaro, C., Rasmussen, T. L., Panieri, G., Mienert, J., Bünz, S., and Sztybor, K.: Carbon isotope $\left(\delta^{13} \mathrm{C}\right)$ excursions suggest times of major methane release during the last $14 \mathrm{kyr}$ in Fram Strait the deep-water gateway to the Arctic, Clim. Past, 11, 669-685, https://doi.org/10.5194/cp-11-669-2015, 2015.

Crane, K., Sundvor, E., Buck, R., and Martinez, F.: Rifting in the northern Norwegian-Greenland Sea: Thermal tests of asymmetric spreading, J. Geophys. Res.-Sol. Ea., 96, 14529-14550, 1991

Crane, K., Doss, H., Vogt, P., Sundvor, E., Cherkashov, G., Poroshina, I., and Joseph, D.: The role of the Spitsbergen shear zone in determining morphology, segmentation and evolution of the Knipovich Ridge, Mar. Geophys. Res., 22, 153-205, 2001.

Crutchley, G. J., Berndt, C., Geiger, S., Klaeschen, D., Papenberg, C., Klaucke, I., Hornbach, M. J., Bangs, N. L., and Maier, C.: Drivers of focused fluid flow and methane seepage at south Hydrate Ridge, offshore Oregon, USA, Geology, 41, 551-554, 2013.

Davies, R. J., Mathias, S. A., Moss, J., Hustoft, S., and Newport, L.: Hydraulic fractures: How far can they go?, Mar. Petrol. Geol., 37, 1-6, 2012.

DeMets, C., Gordon, R. G., and Argus, D. F.: Geologically current plate motions, Geophys. J. Int., 181, 1-80, 2010.

DeVore, J. R. and Sawyer, D. E.: Shear strength of siliciclastic sediments from passive and active margins ( $0-100 \mathrm{~m}$ below seafloor): insights into seismic strengthening, in: Submarine Mass Movements and their Consequences, Springer, Switzerland, 173-180, 2016.

Dickens, G. R.: Down the Rabbit Hole: toward appropriate discussion of methane release from gas hydrate systems during the Paleocene-Eocene thermal maximum and other past hyperthermal events, Clim. Past, 7, 831-846, https://doi.org/10.5194/cp7-831-2011, 2011.

Dumke, I., Burwicz, E. B., Berndt, C., Klaeschen, D., Feseker, T., Geissler, W. H., and Sarkar, S.: Gas hydrate distribution and hydrocarbon maturation north of the Knipovich Ridge, western Svalbard margin, J. Geophys. Res. Sol. Ea., 121, 1405-1424, 2016.

Ehlers, B.-M. and Jokat, W.: Subsidence and crustal roughness of ultra-slow spreading ridges in the northern North Atlantic and the Arctic Ocean, Geophys. J. Int., 177, 451-462, 2009.

Eiken, O. and Hinz, K.: Contourites in the Fram Strait, Sediment. Geol., 82, 15-32, 1993. 
Eldholm, O., Faleide, J. I., and Myhre, A. M.: Continent-ocean transition at the western Barents Sea/Svalbard continental margin, Geology, 15, 1118-1122, 1987.

Engen, Ø., Faleide, J. I., and Dyreng, T. K.: Opening of the Fram Strait gateway: A review of plate tectonic constraints, Tectonophysics, 450, 51-69, 2008.

Faleide, J., Gudlaugsson, S., Eldholm, O., Myhre, A., and Jackson, H.: Deep seismic transects across the sheared western Barents Sea-Svalbard continental margin, Tectonophysics, 189, 73-89, 1991.

Faleide, J. I., Solheim, A., Fiedler, A., Hjelstuen, B. O., Andersen, E. S., and Vanneste, K.: Late Cenozoic evolution of the western Barents Sea-Svalbard continental margin, Global Planet. Change, 12, 53-74, 1996.

Faulkner, D., Jackson, C., Lunn, R., Schlische, R., Shipton, Z., Wibberley, C., and Withjack, M.: A review of recent developments concerning the structure, mechanics and fluid flow properties of fault zones, J. Struct. Geol., 32, 1557-1575, 2010.

Fejerskov, M. and Lindholm, C.: Crustal stress in and around Norway: an evaluation of stress-generating mechanisms, Geol. Soc. Spec. Publ., 167, 451-467, 2000.

Fertl, W.: Abnormal Formation Pressures: implications to exploration, drilling and production of oil and gas reservoirs. Development in Petroleum Science 2, Elsevier Scientific Publications Company, Amsterdam, 1976.

Fjeldskaar, W. and Amantov, A.: Effects of glaciations on sedimentary basins, J. Geodynam., 118, 66-81, 2018.

Franek, P., Plaza-Faverola, A., Mienert, J., Buenz, S., Ferré, B., and Hubbard, A.: Microseismicity linked to gas migration and leakage on the Western Svalbard Shelf, Geochem. Geophys. Geosys., 18, 4623-4645, 2017.

Gaina, C., Nikishin, A., and Petrov, E.: Ultraslow spreading, ridge relocation and compressional events in the East Arctic region: A link to the Eurekan orogeny?, Arktos, 1, 16, https://doi.org/10.1007/s41063-015-0006-8, 2015.

Geersen, J., Scholz, F., Linke, P., Schmidt, M., Lange, D., Behrmann, J. H., Völker, D., and Hensen, C.: Fault zone controlled seafloor methane seepage in the rupture area of the 2010 Maule Earthquake, Central Chile, Geochem. Geophys. Geosys., 17, 4802-4813, 2016.

Gölke, M. and Coblentz, D.: Origins of the European regional stress field, Tectonophysics, 266, 11-24, 1996.

Grauls, D. and Baleix, J.: Role of overpressures and in situ stresses in fault-controlled hydrocarbon migration: A case study, Marine Petrol. Geol., 11, 734-742, 1994.

Grunnaleite, I., Fjeldskaar, W., Wilson, J., Faleide, J., and Zweigel, J.: Effect of local variations of vertical and horizontal stresses on the Cenozoic structuring of the mid-Norwegian shelf, Tectonophysics, 470, 267-283, 2009.

Heidbach, O., Rajabi, M., Reiter, K., and Ziegler, M.: World stress map 2016, Science, 277, 1956-1962, 2016.

Hergert, T. and Heidbach, O.: Geomechanical model of the Marmara Sea region - II. 3-D contemporary background stress field, Geophys. J. Int., 185, 1090-1102, https://doi.org/10.1111/j.1365-246X.2011.04992.x, 2011.

Hillis, R. R.: Coupled changes in pore pressure and stress in oil fields and sedimentary basins, Petrol. Geosci., 7, 419-425, 2001.

Hong, W. L., Sauer, S., Panieri, G., Ambrose, W. G., James, R. H., Plaza-Faverola, A., and Schneider, A.: Removal of methane through hydrological, microbial, and geochemical processes in the shallow sediments of pockmarks along eastern Vestnesa Ridge (Svalbard), Limnol. Oceanogr., 61, https://doi.org/10.1002/lno.10299, 2016.

Hovland, M.: On the self-sealing nature of marine seeps, Cont. Shelf Res., 22, 2387-2394, 2002.

Hovland, M. and Sommerville, J. H.: Characteristics of two natural gas seepages in the North Sea, Marine Petrol. Geol., 2, 319-326, 1985.

Hunter, S., Goldobin, D., Haywood, A., Ridgwell, A., and Rees, J.: Sensitivity of the global submarine hydrate inventory to scenarios of future climate change, Earth Planet. Sc. Lett., 367, 105$115,2013$.

Hustoft, S., Bunz, S., Mienert, J., and Chand, S.: Gas hydrate reservoir and active methane-venting province in sediments on $<20 \mathrm{Ma}$ young oceanic crust in the Fram Strait, offshore NW-Svalbard, Earth Planet. Sc. Lett., 284, 12-24, https://doi.org/10.1016/j.epsl.2009.03.038, 2009.

Hustoft, S., Bünz, S., and Mienert, J.: Three-dimensional seismic analysis of the morphology and spatial distribution of chimneys beneath the Nyegga pockmark field, offshore mid-Norway, Basin Res., 22, 465-480, 2010.

Jakobsson, M., Backman, J., Rudels, B., Nycander, J., Frank, M., Mayer, L., Jokat, W., Sangiorgi, F., O'Regan, M., and Brinkhuis, H.: The early Miocene onset of a ventilated circulation regime in the Arctic Ocean, Nature, 447, 986-990, 2007.

Jansen, E. and Sjøholm, J.: Reconstruction of glaciation over the past $6 \mathrm{Myr}$ from ice-borne deposits in the Norwegian Sea, Nature, 349, 600, https://doi.org/10.1038/349600a0, 1991.

Jansen, E., Sjøholm, J., Bleil, U., and Erichsen, J.: Neogene and Pleistocene glaciations in the northern hemisphere and late Miocene-Pliocene global ice volume fluctuations: Evidence from the Norwegian Sea, in: Geological History of the Polar Oceans: Arctic versus Antarctic, Springer, Dordrecht, 677-705, 1990.

Johnson, J. E., Mienert, J., Plaza-Faverola, A., Vadakkepuliyambatta, S., Knies, J., Bünz, S., Andreassen, K., and Ferré, B.: Abiotic methane from ultraslow-spreading ridges can charge Arctic gas hydrates, Geology, 36441, G36440, https://doi.org/10.1130/G36440.1, 2015.

Jokat, W., Lehmann, P., Damaske, D., and Nelson, J. B.: Magnetic signature of North-East Greenland, the Morris Jesup Rise, the Yermak Plateau, the central Fram Strait: constraints for the rift/drift history between Greenland and Svalbard since the Eocene, Tectonophysics, 691, 98-109, 2016.

Judd, A. and Hovland, M.: Seabed fluid flow: the impact on geology, biology and the marine environment, Cambridge University Press, Cambridge, 2009.

Jung, N.-H., Han, W. S., Watson, Z., Graham, J. P., and Kim, K.Y.: Fault-controlled $\mathrm{CO}_{2}$ leakage from natural reservoirs in the Colorado Plateau, East-Central Utah, Earth Planet. Sc. Lett., 403, 358-367, 2014.

Karstens, J. and Berndt, C.: Seismic chimneys in the Southern Viking Graben-Implications for palaeo fluid migration and overpressure evolution, Earth Planet. Sci. Lett., 412, 88-100, 2015.

Karstens, J., Haflidason, H., Becker, L. W. M., Berndt, C., Rüpke, L., Planke, S., Liebetrau, V., Schmidt, M., and Mienert, J.: Glacigenic sedimentation pulses triggered post- 
glacial gas hydrate dissociation, Nature Comm., 9, 635, https://doi.org/10.1038/s41467-018-03043-z, 2018.

Keiding, M., Lund, B., and Árnadóttir, T.: Earthquakes, stress, and strain along an obliquely divergent plate boundary: Reykjanes Peninsula, southwest Iceland, J. Geophys. Res.-Sol. Ea., 114, https://doi.org/10.1029/2008JB006253, 2009.

Knies, J., Matthiessen, J., Vogt, C., Laberg, J. S., Hjelstuen, B. O., Smelror, M., Larsen, E., Andreassen, K., Eidvin, T., and Vorren, T. O.: The Plio-Pleistocene glaciation of the Barents Sea-Svalbard region: a new model based on revised chronostratigraphy, Quaternary Sci. Rev., 28, 812-829, https://doi.org/10.1016/j.quascirev.2008.12.002, 2009.

Knies, J., Daszinnies, M., Plaza-Faverola, A., Chand, S., Sylta, Ø., Bünz, S., Johnson, J. E., Mattingsdal, R., and Mienert, J.: Modelling persistent methane seepage offshore western Svalbard since early Pleistocene, Marine Petrol. Geol., 91, 800-811, 2018.

Lindholm, C. D., Bungum, H., Hicks, E., and Villagran, M.: Crustal stress and tectonics in Norwegian regions determined from earthquake focal mechanisms, Geol. Soc. Spec. Pub., 167, 429-439, 2000.

Lund, B. and Townend, J.: Calculating horizontal stress orientations with full or partial knowledge of the tectonic stress tensor, Geophys. J. Int., 170, 1328-1335, 2007.

Lund, B. and Schmidt, P.: Stress evolution and fault stability at Olkiluoto during the Weichselian glaciation, Report for Posiva Oy, 2011.

Lund, B., Schmidt, P., and Hieronymus, C.: Stress evolution and fault stability during the Weichselian glacial cycle, Swedish $\mathrm{Nu}-$ clear Fuel and Waste Management Co, Stockholm, Sweden, Tech. Rep. TR-09-15, 2009.

Madrussani, G., Rossi, G., and Camerlenghi, A.: Gas hydrates, free gas distribution and fault pattern on the west Svalbard continental margin, Geophys. J. Int., 180, 666-684, 2010.

Massonnet, D., Rossi, M., Carmona, C., Adragna, F., Peltzer, G., Feigl, K., and Rabaute, T.: The displacement field of the Landers earthquake mapped by radar interferometry, Nature, 364, 138, https://doi.org/10.1038/364138a0, 1993.

Mattingsdal, R., Knies, J., Andreassen, K., Fabian, K., Husum, K., Grøsfjeld, K., and De Schepper, S.: A new 6 Myr stratigraphic framework for the Atlantic-Arctic Gateway, Quaternary Sci. Rev., 92, 170-178, 2014.

Mau, S., Römer, M., Torres, M. E., Bussmann, I., Pape, T., Damm, E., Geprägs, P., Wintersteller, P., Hsu, C.-W., and Loher, M.: Widespread methane seepage along the continental margin off Svalbard-from Bjørnøya to Kongsfjorden, Sci. Rep., 7, 42997, https://doi.org/10.1038/srep42997, 2017.

Minshull, T. and White, R.: Sediment compaction and fluid migration in the Makran accretionary prism, J. Geophys. Res.-Sol. Ea., 94, 7387-7402, 1989.

Moore, J. C. and Vrolijk, P.: Fluids in accretionary prisms, Rev. Geophys., 30, 113-135, 1992.

Morgan, W. J.: 13. Hotspot tracks and the opening of the Atlantic and Indian Oceans; in Global Coastal Oceans: Multiscale multidisciplinary processes, The oceanic lithosphere, Harvard University Press, London, 443-487, 1981.

Myhre, A. M. and Eldholm, O.: The western Svalbard margin (74$\left.80^{\circ} \mathrm{N}\right)$, Marine Petrol. Geol., 5, 134-156, 1988.
Naliboff, J., Lithgow-Bertelloni, C., Ruff, L., and de Koker, N.: The effects of lithospheric thickness and density structure on Earth's stress field, Geophys. J. Int., 188, 1-17, 2012.

Nasuti, A. and Olesen, O.: Chapter 4: Magnetic data, in: Tectonostratigraphic Atlas of the North-East Atlantic Region, edited by: Hopper, J. R., Funck, T., Stoker, T., Arting, U., Peron-Pinvidic, G., Doornebal, H., and Gaina, C., Geological Survey of Denmark and Greenland (GEUS), Copenhagen, Denmark, 41-51, 2014.

Okada, Y.: Surface deformation due to shear and tensile faults in a half-space, B. Seismol. Soc. Am., 75, 1135-1154, 1985.

Olesen, O., Bungum, H., Dehls, J., Lindholm, C., Pascal, C., and Roberts, D.: Neotectonics, seismicity and contemporary stress field in Norway-mechanisms and implications, Quaternary Geology of Norway, in: Geological Survey of Norway Special Publication, 13, 145-174, 2013.

Panieri, G., Bünz, S., Fornari, D. J., Escartin, J., Serov, P., Jansson, P., Torres, M. E., Johnson, J. E., Hong, W., and Sauer, S.: An integrated view of the methane system in the pockmarks at Vestnesa Ridge, 79 N, Marine Geol., 390, 282-300, 2017.

Patton, H., Hubbard, A., Andreassen, K., Winsborrow, M., and Stroeven, A. P.: The build-up, configuration, and dynamical sensitivity of the Eurasian ice-sheet complex to Late Weichselian climatic and oceanic forcing, Quaternary Sci. Rev., 153, 97-121, 2016.

Petersen, C. J., Bünz, S., Hustoft, S., Mienert, J., and Klaeschen, D.: High-resolution P-Cable 3-D seismic imaging of gas chimney structures in gas hydrated sediments of an Arctic sediment drift, Marine Petrol. Geol., 27, 1-14, https://doi.org/10.1016/j.marpetgeo.2010.06.006, 2010.

Planke, S., Eriksen, F. N., Berndt, C., Mienert, J., and Masson, D.: P-Cable high-resolution seismic, Oceanography, 22, 1-85, 2009.

Plaza-Faverola, A., Bünz, S., and Mienert, J.: Repeated fluid expulsion through sub-seabed chimneys offshore Norway in response to glacial cycles, Earth Planet. Sc. Lett., 305, 297-308, https://doi.org/10.1016/j.epsl.2011.03.001, 2011.

Plaza-Faverola, A., Bünz, S., Johnson, J. E., Chand, S., Knies, J., Mienert, J., and Franek, P.: Role of tectonic stress in seepage evolution along the gas hydrate-charged Vestnesa Ridge, Fram Strait, Geophys. Res. Lett., 42, 733-742, 2015.

Plaza-Faverola, A., Henrys, S., Pecher, I., Wallace, L., and Klaeschen, D.: Splay fault branching from the Hikurangi subduction shear zone: Implications for slow slip and fluid flow, Geochem. Geophys. Geosys., 17, 5009-5023, 2016.

Plaza-Faverola, A., Vadakkepuliyambatta, S., Hong, W. L., Mienert, J., Bünz, S., Chand, S., and Greinert, J.: Bottom-simulating reflector dynamics at Arctic thermogenic gas provinces: an example from Vestnesa Ridge, offshore west-Svalbard, J. Geophys. Res.-Sol. Ea., https://doi.org/10.1002/2016JB013761, 2017.

Portnov, A., Vadakkepuliyambatta, S., Mienert, J., and Hubbard, A.: Ice-sheet-driven methane storage and release in the Arctic, Nat. Commun., 7, 10314, https://doi.org/10.1038/ncomms10314, 2016.

Riboulot, V., Thomas, Y., Berné, S., Jouet, G., and Cattaneo, A.: Control of Quaternary sea-level changes on gas seeps, Geophys. Res. Lett., 41, 4970-4977, 2014.

Riedel, M., Wallmann, K., Berndt, C., Pape, T., Freudenthal, T., Bergenthal, M., Bünz, S., and Bohrmann, G.: In situ temperature measurements at the Svalbard Continental Margin: Implica- 
tions for gas hydrate dynamics, Geochem. Geophys. Geosys., 19, 1165-1177, 2018.

Roy, S., Senger, K., Braathen, A., Noormets, R., Hovland, M., and Olaussen, S.: Fluid migration pathways to seafloor seepage in inner Isfjorden and Adventfjorden, Svalbard, Norwegian J. Geol., 94, 99-119, 2014.

Salomatin, A. and Yusupov, V.: Acoustic investigations of gas "flares" in the Sea of Okhotsk, Oceanology, 51, 911-919, 2011.

Salomon, E., Koehn, D., Passchier, C., Hackspacher, P. C., and Glasmacher, U. A.: Contrasting stress fields on correlating margins of the South Atlantic, Gondwana Res., 28, 1152-1167, 2015.

Schiffer, C., Tegner, C., Schaeffer, A. J., Pease, V., and Nielsen, S. B.: High Arctic geopotential stress field and implications for geodynamic evolution, Geol. Soc. Spec. Pub., 460, 441-465, 2018.

Schneider, A., Panieri, G., Lepland, A., Consolaro, C., Crémière, A., Forwick, M., Johnson, J., Plaza-Faverola, A., Sauer, S., and Knies, J.: Methane seepage at Vestnesa Ridge (NW Svalbard) since the Last Glacial Maximum, Quaternary Sci. Rev., 193, 98 117, 2018a.

Schneider, A., Panieri, G., Lepland, A., Consolaro, C., Crémière, A., Forwick, M., Johnson, J. E., PlazaFaverola, A., Sauer, S., and Knies, J.: Methane seepage at Vestnesa Ridge (NW Svalbard) since the Last Glacial Maximum, Quaternary Science Reviews, 193, 98-117, https://doi.org/10.1016/j.quascirev.2018.06.006, 2018 b.

Sibson, R. H.: Crustal stress, faulting and fluid flow, Geol. Soc. Spec. Pub., 78, 69-84, 1994.

Skarke, A., Ruppel, C., Kodis, M., Brothers, D., and Lobecker, E.: Widespread methane leakage from the sea floor on the northern US Atlantic margin, Nat. Geosci., 7, 657-661, 2014.

Smith, A. J., Mienert, J., Bünz, S., and Greinert, J.: Thermogenic methane injection via bubble transport into the upper Arctic Ocean from the hydrate-charged Vestnesa Ridge, Svalbard, Geochem., Geophys. Geosys., https://doi.org/10.1002/2013GC005179, 2014.

Somoza, L., León, R., Medialdea, T., Pérez, L. F., González, F. J., and Maldonado, A.: Seafloor mounds, craters and depressions linked to seismic chimneys breaching fossilized diagenetic bottom simulating reflectors in the central and southern Scotia Sea, Antarctica, Global Planet. Change, 123, 359-373, 2014.

Steffen, H., Kaufmann, G., and Wu, P.: Three-dimensional finite-element modeling of the glacial isostatic adjustment in Fennoscandia, Earth Planet. Sc. Lett., 250, 358-375, 2006.

Stein, S., Cloetingh, S., Sleep, N. H., and Wortel, R.: Passive margin earthquakes, stresses and rheology, in: Earthquakes at North-Atlantic Passive Margins: Neotectonics and Postglacial Rebound, Springer, Dordrecht, 231-259, 1989.

Svensen, H., Planke, S., Malthe-Sørenssen, A., Jamtveit, B., Myklebust, R., Eidem, T. R., and Rey, S. S.: Release of methane from a volcanic basin as a mechanism for initial Eocene global warming, Nature, 429, 542-545, 2004.

Sztybor, K. and Rasmussen, T. L.: Diagenetic disturbances of marine sedimentary records from methane-influenced environments in the Fram Strait as indications of variation in seep intensity during the last 35000 years, Boreas, 46, 212-228, 2017a.
Sztybor, K. and Rasmussen, T. L.: Late glacial and deglacial palaeoceanographic changes at Vestnesa Ridge, Fram Strait: Methane seep versus non-seep environments, Palaeogeogr. Palaeocl., 476, 77-89, 2017b.

Turcotte, D., Ahern, J., and Bird, J.: The state of stress at continental margins, Tectonophysics, 42, 1-28, 1977.

Turcotte, D. L. and Schubert, G.: Geodynamics, Cambridge University Press, New York, 2002.

Urlaub, M., Talling, P. J., Zervos, A., and Masson, D.: What causes large submarine landslides on low gradient $\left(<2^{\circ}\right)$ continental slopes with slow $(\sim 0.15 \mathrm{~m} / \mathrm{kyr})$ sediment accumulation?, J. Geophys. Res.-Sol .Ea., 120, 6722-6739, 2015.

Vanneste, M., Guidard, S., and Mienert, J.: Arctic gas hydrate provinces along the western Svalbard continental margin, NPF Sp. Publ., 12, 271-284, 2005.

Vis, G.-J.: Geology and seepage in the NE Atlantic region, Geol. Soc. Spec. Pub., 447, 416, https://doi.org/10.1144/SP447.16, 2017.

Vogt, P. R., Crane, K., Sundvor, E., Max, M. D., and Pfirman, S. L.: Methane-generated (?) pockmarks on young, thickly sedimented oceanic crust in the Arctic: Vestnesa ridge, Fram strait, Geology, 22, 255-258, 1994.

Waghorn, K. A., Bünz, S., Plaza-Faverola, A., and Johnson, J. E.: 3D Seismic Investigation of a Gas Hydrate and Fluid Flow System on an Active Mid-Ocean Ridge; Svyatogor Ridge, Fram Strait, Geochem. Geophys. Geosys., 19, 2325-2341, https://doi.org/10.1029/2018GC007482, 2018.

Wallmann, K., Riedel, M., Hong, W., Patton, H., Hubbard, A., Pape, T., Hsu, C., Schmidt, C., Johnson, J., and Torres, M.: Gas hydrate dissociation off Svalbard induced by isostatic rebound rather than global warming, Nat. Commun., 9, 83, https://doi.org/10.1038/s41467-017-02550-9, 2018.

Westbrook, G. K., Thatcher, K. E., Rohling, E. J., Piotrowski, A. M., Palike, H., Osborne, A. H., Nisbet, E. G., Minshull, T. A., Lanoiselle, M., James, R. H., Huhnerbach, V., Green, D., Fisher, R. E., Crocker, A. J., Chabert, A., Bolton, C., Beszczynska-Moller, A., Berndt, C., and Aquilina, A.: Escape of methane gas from the seabed along the West Spitsbergen continental margin, Geophys. Res. Lett., 36, L15608, https://doi.org/10.1029/2009g1039191, 2009.

Wright, T. J., Ebinger, C., Biggs, J., Ayele, A., Yirgu, G., Keir, D., and Stork, A.: Magma-maintained rift segmentation at continental rupture in the 2005 Afar dyking episode, Nature, 442, 291, https://doi.org/10.1038/nature04978 https://www.nature. com/articles/nature04978\#supplementary-information (last access: 14 January 2019), 2006.

Zoback, M. D. and Zoback, M. L.: State ofstress in the Earth's lithosphere, inInternationalHandbook of Earthquake and Engineering Seismology, Int. Geophys. Ser., edited by: Lee, W. H. K., Jennings, P. C., and Kanamori, H., 559-568, Academic Press, Amsterdam, 2002. 